University of Nebraska - Lincoln

DigitalCommons@University of Nebraska - Lincoln

Agronomy \& Horticulture -- Faculty Publications

Agronomy and Horticulture Department

4-1924

\title{
Absorption of Nutrients From Subsoil in Relation to Crop Yield
}

John W. Crist

J. E. Weaver

University of Nebraska-Lincoln

Follow this and additional works at: https://digitalcommons.unl.edu/agronomyfacpub

Part of the Plant Sciences Commons

Crist, John W. and Weaver, J. E., "Absorption of Nutrients From Subsoil in Relation to Crop Yield" (1924). Agronomy \& Horticulture -- Faculty Publications. 431.

https://digitalcommons.unl.edu/agronomyfacpub/431

This Article is brought to you for free and open access by the Agronomy and Horticulture Department at DigitalCommons@University of Nebraska - Lincoln. It has been accepted for inclusion in Agronomy \& Horticulture -Faculty Publications by an authorized administrator of DigitalCommons@University of Nebraska - Lincoln. 


\title{
THE
}

\section{BOTANICAL GAZETTE} April I924

\author{
ABSORPTION OF NUTRIENTS FROM SUBSOIL IN \\ RELATION TO CROP YIELD \\ JohN W. CRIST AND J. E. WEAVER
}

(WITH NINE FIGURES)

Investigations of the development of root systems of native and crop plants have been pursued for a number of years at the University of Nebraska. The gradual intensification of this work has led to a type of experimentation designed to discover the nature of the activities of roots at great depths in relation to absorption of water and nutrients. In the present investigation the effects of absorption of nutrients from deep levels upon quantity and quality of yield were determined. Studies on the amounts of water and nitrates removed by crops from various soil levels were begun in rgr9, but little attention was then given to yield. Since the results of these earlier experiments have a direct bearing upon the present problem, however, the methods employed being essentially the same, the more important results will be briefly summarized (cf. Weaver, Jean, and Crist 20).

Containers $1.5^{-3}$ feet in diameter and $2.5^{-5}$ feet deep were employed. They were placed in trenches, which were then refilled with soil, and crops planted around the containers in such a manner that the experimental crops in the containers were grown under field conditions. The containers were filled with well mixed soil of known water content and physical and chemical composition, to which, at certain levels, $\mathrm{NaNO}_{3}$ had been added at the rate of 
400 parts per million. The containers were filled in such a manner that the well compacted soil at any level occupied the same relative position as regards depth that it had occupied before removal from the field. The fertilized layers, and in some cases every 6-inch layer, were separated from the rest of the soil by wax seals which prevented the movement of water or solutes, but through which the roots readily penetrated. To prevent water intake, each container was furnished with an appropriate wooden roof. Crops of Manchuria barley, early Ohio potatoes, and maize were grown. In order to study the activities of the roots at various stages in their development, enough containers were used so that some could be examined at each of the several periods of growth. In fig. I, containers $\mathrm{I}$ and 2 illustrate diagrammatically the development of the roots of barley when 55 days old and in the 6 or 7 leaf stage. In containers 3,4 , and 5 the crop was in blossom (74 days old), while in 6 and 7 it had reached maturity. The horizontal lines indicate the positions of the wax seals, and the double vertical lines the positions of the 6-inch levels to which the nutrient was added. The numbers at the bottoms of the containers give the nitrates in parts per million, based on the dry weight of the soil, absorbed from the fertilized layers. The gains by nitrification at the several levels were determined from the control container (no. 8), without a crop.

The amount of water absorbed by barley from the deeper soil (to 3.5 feet) was in direct relation to the growth of the root system into these deeper layers. The total amounts absorbed to depths of 2.5 feet in general were practically the same from the several 6 -inch levels. Corn is an extravagant user of water, absorbing large quantities from the third and fourth foot of soil, and smaller amounts from the fifth foot. Potatoes absorbed water to depths of 2.5 feet. Potatoes used the nitrates in smaller amounts than barley. When beginning to blossom (74 days old) they had removed I43 and 70 parts per million of nitrates from the I-I.5 and $I \cdot 5^{-2}$ foot layers respectively, and when beginning to ripen (Ioo days old) they had removed 228 parts per million at a depth of $I^{-5}-2$ feet, and 76 to 165 parts per million at the $2-2.5$ foot level. Corn removed 203, I40, and II 8 parts per million at depths of 3 , 4 , and 5 feet respectively. 
From these experiments we may conclude that (I) the roots of crop plants are active in the absorption of both water and nitrate salts, even at the maximum depth of their penetration; (2) both water and nitrates are taken up from these lower portions of the soil in considerable quantities, although to a less extent than from

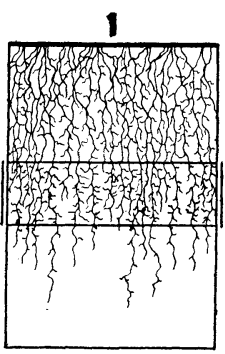

168

5

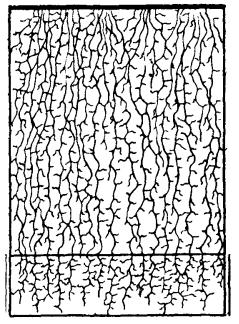

168

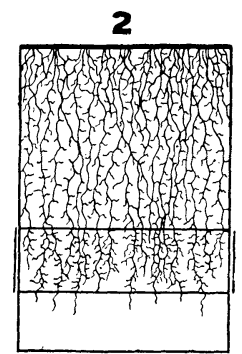

145

6

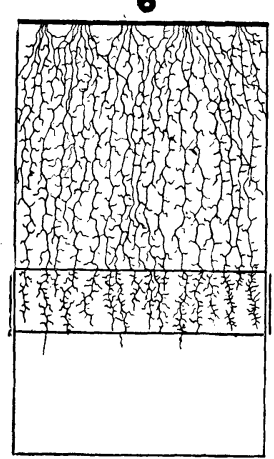

139

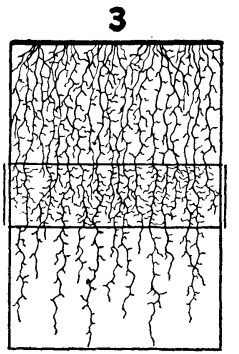

286

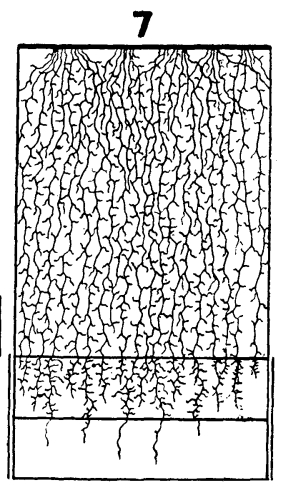

186

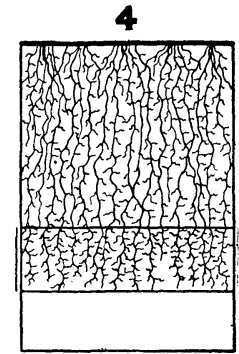

135

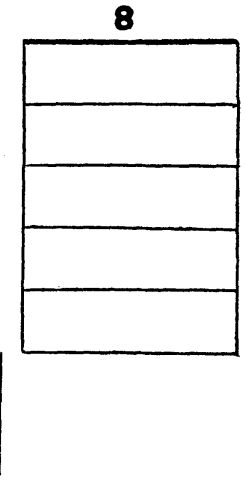

FIG. I.-Diagrammatic representation of root development of barley at three different stages in growth; $\mathrm{NaNO}_{3}$ occurred at several levels delimited by double vertical lines and horizontal lines, latter represent wax seals.

the more superficial portions; (3) the plants receive this supply of water and nitrogen from the deeper soil layers during the later and perhaps more critical stages of their development; (4) the roots branch more profusely and are more abundant where they come in contact with the fertilizer; and (5) there is urgent need for a series of experiments to ascertain the significance of absorption at great depths in relation to quantity and quality of crop yield. 
An extensive literature elucidating the problem of fertilizers and their effects upon yield of the various economic crops has been produced. Practically none of it refers to the present type of investigation, because in all experimental tests and agricultural practices the application of fertilizer has been restricted to the surface or merely to the first four to eight inches of the soil. Among soil scientists it has long been the custom to take samples to depths as great as 4-6 feet and occasionally even deeper. While slight attention has usually been given to the composition of the deeper samples, yet it has meant a degree of recognition of the importance of the nature of the deeper soil and soil solution. Serious consideration of the lower subsoil has been taken only when it was of rock or contained a hardpan, or, in some other way than through a deficiency of nutrient substances became detrimental to crop production (I9).

\section{Experimental methods}

Large, water tight oak barrels 22 inches in minimum diameter and 30 inches deep were used as containers. Sufficient soil to fill them was obtained from the first 2.5 feet of the soil in the field in which the experimental work was done. The soil was low in both nitrate nitrogen and active phosphoric acid (table I). While crops

TABLE I

$\mathrm{NO}_{3}$ AND $\mathrm{P}_{2} \mathrm{O}_{5}$ CONTENT OF SOILS

\begin{tabular}{c|c|c|c}
\hline \hline Soil & $\begin{array}{c}\text { Depth } \\
\text { (ft.) }\end{array}$ & $\begin{array}{c}\text { Nitrate }\left(\mathrm{NO}_{3}\right) \\
\text { (p.p.m.) }\end{array}$ & $\begin{array}{c}\mathrm{P}_{2} \mathrm{O}_{5} \\
\text { (per cent) }\end{array}$ \\
\hline Surface.......... & $\begin{array}{c}\text { O-I } \\
\text { Subsoil.......... }\end{array}$ & $\begin{array}{c}99.5 \\
\text { I I . I }\end{array}$ & $\begin{array}{c}\text { O. O29 } \\
\text { O. OI } 2\end{array}$ \\
\hline
\end{tabular}

on eastern Nebraska soils respond readily and consistently to nitrate fertilizers, experiments conducted by the department of agronomy of the University of Nebraska (unpublished data) have shown that phosphorus fertilizers have failed to stimulate production.

On March 27, I922, two trenches were dug in the field where the crops were to be grown, and the containers, 18 in number, placed in them in rows with the tops about 4 inches above the general soil level. The soil had previously been brought to an approximately uniform water content of about 27 per cent. As the several 
containers were filled, samples were taken at each level for moisture determinations, and also, where necessary, for the determination of nitrates. The fertilized layers were separated from the soil, both above and below, by means of wax seals, which consisted of 85 per cent paraffin and I 5 per cent petrolatum. The seal was applied hot, so that it penetrated a little into the soil, and when it cooled clung tenaciously to the soil particles. It varied from 2 to $3 \mathrm{~mm}$. in thickness. As shown in previous investigations, the seal

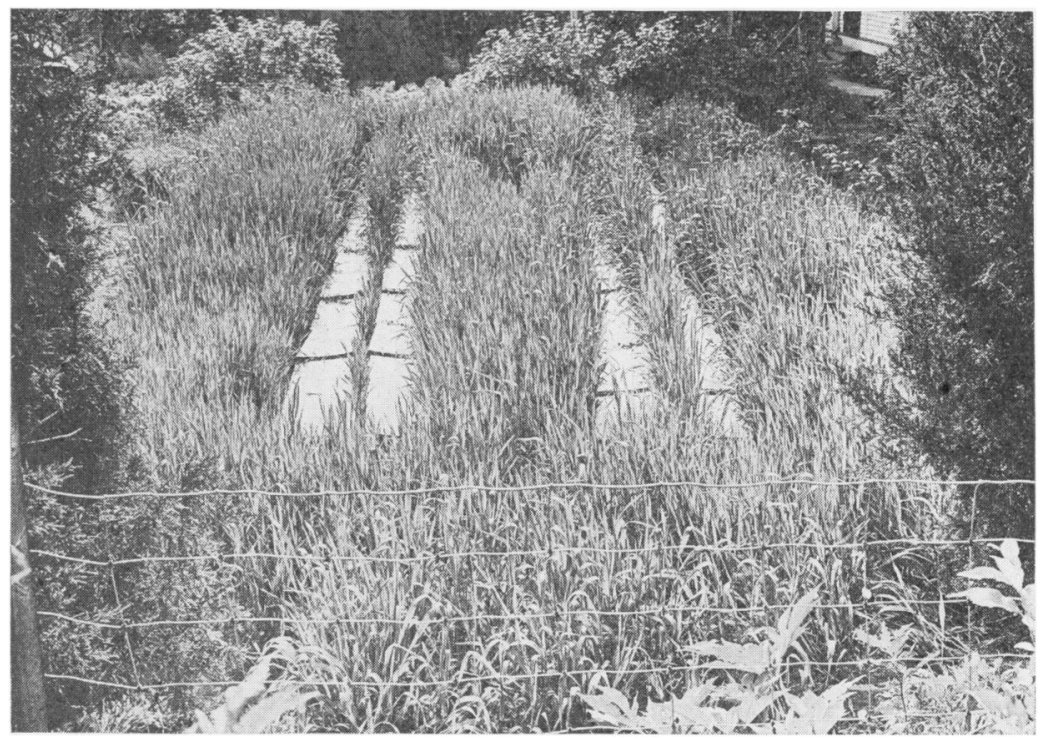

FIG. 2.-General view of experimental plat on May 29.

has no effect upon root development (20). The nutrient salts used were chemically pure monocalcium phosphate and sodium nitrate. The phosphate was applied at the rate of $\mathrm{I} \mathrm{gm}$. to $30 \mathrm{lb}$. of soil, which is approximately equivalent to 500 pounds of acid phosphate per acre. The nitrate was added at the rate of 292 parts per million of $\mathrm{NO}_{3}$ on the basis of the dry weight of the soil.

When the containers had been filled to within 2 inches of the top, two thin wooden strips, about I.5 inches in width and as long as the diameters of the containers, were placed edgewise and partially sunk into the soil so as to prevent the wax seal from cover- 
ing the area of soil (about $\mathrm{I} .5$ inches in width) in which the crops were to be planted. Finally, the wax seal was covered with 2 inches of sand. Next a light green wooden roof, with sufficient slope to cause the water to run off, but with an opening $\mathrm{I} .5$ inches wide and as long as the diameter of the container, was fastened in place. A small amount of soil was placed in the openings thus left, and after the crop was planted about an inch of dry soil added to check evaporation (fig. 2). Seeds of Manchuria barley, selected

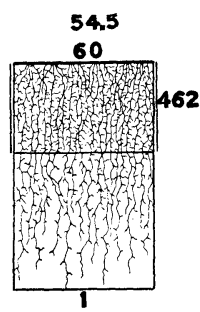

490

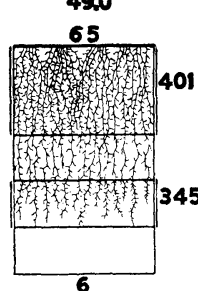

401

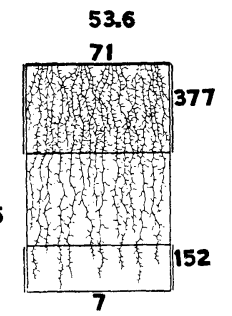

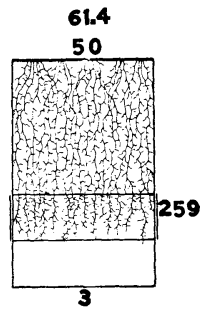

60.1

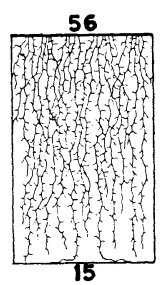

80.9

36

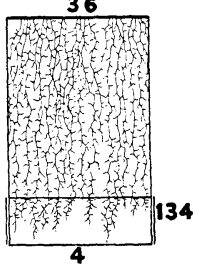

70.0

43

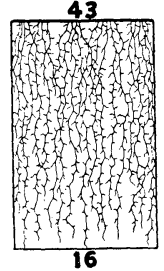

50.7

70

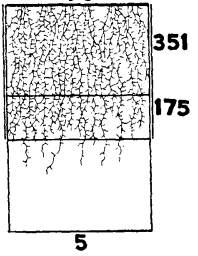

72.7

43

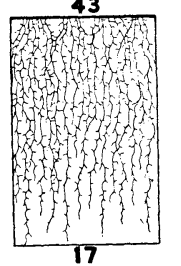

FIG. 3.-Diagrammatic representation of root development of barley fertilized with $\mathrm{NaNO}_{3}$; seals and position of fertilizer indicated as in fig. I; numbers immediately above containers represent number of plants, those higher, average length of stalks in centimeters.

for uniformity in size and previously treated with formalin solution to prevent smut infection, were sown on April 7, roo seeds per container.

The position of the fertilized layers in the several containers in the nitrogen series, together with the unfertilized control crops, is shown in fig. 3, which also illustrates the relative root development at the time of harvest, June 26 . The positions of the wax seals are indicated by horizontal lines and that of the fertilizer by double vertical lines. A control container without a crop or fertilizer, but sealed at every 6-inch level, was used as a check to determine the 
extent of nitrification and denitrification. Root development, etc., at the time of harvest on June 24, is shown for the phosphorus series in fig. 4 .

On May 2, when germination was completed and most of the seedlings had reached the second leaf stage, they were thinned to 35 per container. Eleven days later, just as tillering was beginning, enough of the smaller plants were removed to leave only 30 plants
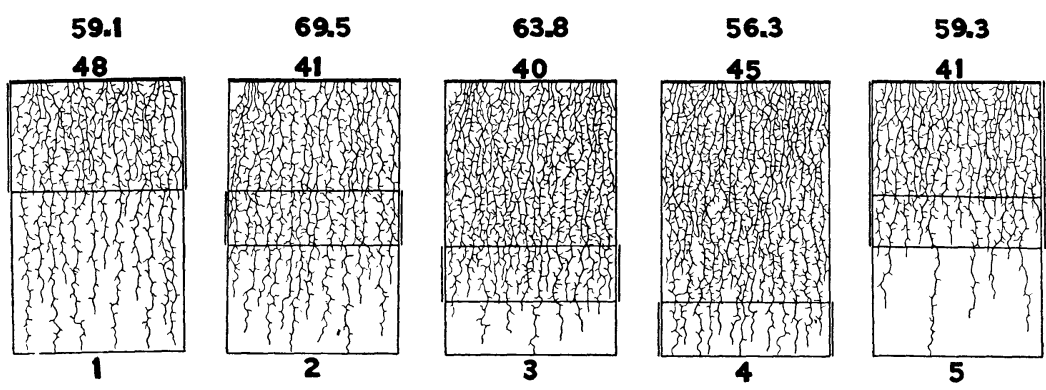

63.7

60.9

60.1

31
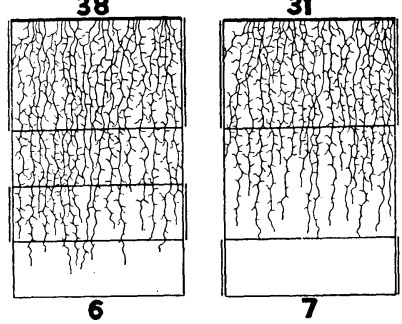

56

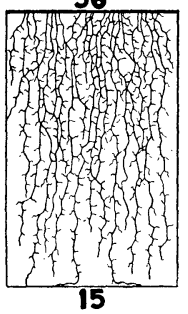

70.0

72.7

43

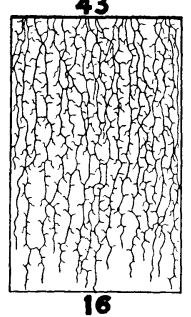

43

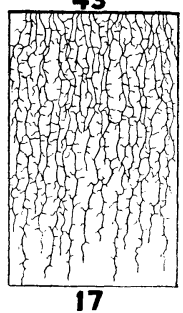

FIG. 4.-Diagrammatic representation of root development of barley fertilized with $\mathrm{CaH}_{4}\left(\mathrm{PO}_{4}\right)_{2}$; seals, position of fertilizer, number of plants, and length of stalks indicated as in fig. 3 .

in each container, a number not in excess of that growing in a similar soil area under field conditions. The growth of the crops in the containers, as in previous experiments, paralleled that of the crop surrounding them, except for such differences as were caused by the fertilizer, which could readily be observed upon comparison with the controls. On May 22, and again on June $\mathrm{I} 7$, when very hot dry weather prevailed, the experimental crops were watered, the same amount of water ( $\mathrm{I}$ liter on the first date and 3 liters on the 
second) being poured slowly into each container through the narrow openings through which the plants were growing. By June I the crop was heading. June ro-22 was a period of dry and unusually hot weather, which resulted in the general harvest of eastern $\mathrm{Ne}$ braska being at least to days earlier than usual. The experimental crops ripened very rapidly, and were harvested on June 24 and 26 respectively, the phosphorus series maturing first.

In harvesting the crop, the plants were cut off at the surface of the soil. Those from each container were wrapped separately in muslin cloths and taken to the laboratory, where they were spread out on tables in a well ventilated, well lighted room and allowed to dry. When thoroughly dry, the various measurements were taken, weights determined, and analyses made. In taking down the containers, they were tilted on their sides in the trench, the hoops chiseled off, the top staves removed, and the exposed core of the soil taken out in 6-inch sections in examining root development and obtaining samples for analyses. All soil samples for chemical analyses were taken in large composite form. Those to be analyzed for nitrates were treated with small amounts of toluol and sealed at once in mason jars. In the nitrate determinations the method of Whitrng (2I) was employed. Phosphorus determinations were made by digestion in fifth normal nitric acid for 5 hours at $40^{\circ} \mathrm{C}$. This gave the quantity of the so-called active phosphoric acid (Fraps 6). The usual modified Gunning method was used in the analyses of grain and straw for nitrogen. Determinations of phosphorus in the grain and straw were made by digesting the samples with concentrated nitric acid in the presence of $\mathrm{MgO}$, followed by precipitation from the extract with ammonium molybdate and the other steps in the gravimetric process.

\section{Experimental results}

Nitrate SERIES

The growth of root and shoot and the amounts of water and nitrates removed by the crop in the nitrate series, together with the water loss from the controls, are shown in table II. These data show the remarkable activity of roots in the absorption of both water and nitrates in the lower soil levels. Notwithstanding the 
TABLE II

Loss of water and nitrates April 7 to JUne 26

\begin{tabular}{|c|c|c|c|c|c|c|c|c|c|c|}
\hline \multirow[b]{2}{*}{$\begin{array}{l}\text { CONTAINER AND CROP } \\
\text { DEVELOPMENT }\end{array}$} & \multirow[b]{2}{*}{$\begin{array}{c}\text { DEPTH } \\
\text { IN } \\
\text { FEET }\end{array}$} & \multicolumn{3}{|c|}{ WATER CONTENT } & \multicolumn{6}{|c|}{ NITRATE $\left(\mathrm{NO}_{3}\right)$ PARTS PER MILLION } \\
\hline & & $\left|\begin{array}{c}\text { April 7 } \\
\text { (per } \\
\text { cent) }\end{array}\right|$ & $\begin{array}{c}\text { June } \\
26 \\
\text { (per } \\
\text { cent) }\end{array}$ & $\begin{array}{c}\text { Loss } \\
\text { (per } \\
\text { cent) }\end{array}$ & \begin{tabular}{|c} 
Origi- \\
nal \\
con- \\
tent \\
April 7
\end{tabular} & $\begin{array}{c}\text { Im- } \\
\text { preg- } \\
\text { nation } \\
\text { April } 7\end{array}$ & $\begin{array}{l}\text { Gain } \\
\text { by } \\
\text { nitri- } \\
\text { fica- } \\
\text { tion }\end{array}$ & Total & $\underset{26}{\text { June }}$ & Loss \\
\hline $\begin{array}{l}\text { No. I: } \\
60 \text { stalks, average length } \\
54.5 \mathrm{~cm} ., 42 \text { heads; roots } \\
\text { well developed in first } \\
\text { foot, abundant to I.5 feet, } \\
\text { and fairly abundant to } 2.5 \\
\text { feet }\end{array}$ & $\begin{array}{l}0-I \\
I-I \cdot 5 \\
I \cdot 5-2 \\
2-2 \cdot 5\end{array}$ & $\begin{array}{l}22.3 \\
22.4 \\
23.8 \\
23.3\end{array}$ & $\begin{array}{l}\text { II .2 } \\
\text { I6.9 } \\
\text { I } 7.1 \\
\text { I } 8.3\end{array}$ & $\begin{array}{r}\text { II . I } \\
5.5 \\
6.7 \\
5.0\end{array}$ & $\left|\begin{array}{c}99 \cdot 5 \\
\cdots \cdots \\
\cdots \cdots \\
\cdots \cdots\end{array}\right|$ & $\begin{array}{c}356.8 \\
\cdots \cdots \\
\cdots \cdots \\
\cdots \cdots\end{array}$ & $\begin{array}{c}70.7 \\
\cdots \cdots \\
\cdots \cdots \\
\cdots \cdots \\
\cdots \cdots\end{array}$ & $\mid \begin{array}{c}527 \\
\cdots \cdots \\
\cdots \cdots \\
\cdots \cdots \\
\end{array}$ & $\begin{array}{c}64.4 \\
\cdots \cdots \\
\cdots \cdots \\
\cdots \cdots \\
\cdots\end{array}$ & $\begin{array}{c}462.6 \\
\cdots \cdots \\
\cdots \cdots \\
\cdots \cdots\end{array}$ \\
\hline $\begin{array}{l}\text { No. } 2 \text { : } \\
57 \text { stalks, average length } \\
58.6 \mathrm{~cm} ., 43 \text { heads; roots } \\
\text { well developed in first } \\
\text { foot, very abundant at } \\
\text { I-I.5 feet, but sparse to } \\
2 \text { feet, a few extended to } \\
\text { 2.I feet }\end{array}$ & $\begin{array}{l}0-I \\
I-I \cdot 5 \\
I .5-2 \\
2-2 \cdot 5\end{array}$ & $\begin{array}{l}24.8 \\
22.6 \\
22.8 \\
25.2\end{array}$ & $\begin{array}{l}\text { II .I } \\
\text { I6.8 } \\
\text { I8.0 } \\
25.0\end{array}$ & $\begin{array}{r}13.7 \\
5.8 \\
4.8 \\
0.2\end{array}$ & 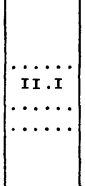 & 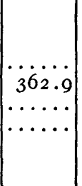 & $\begin{array}{c}\ldots \ldots \\
24.9 \\
\ldots \ldots \\
\cdots \ldots\end{array}$ & $\mid \begin{array}{c}\cdots \cdots \\
398.9 \\
\cdots \cdots \\
\cdots \cdots\end{array}$ & 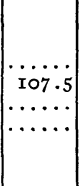 & $\begin{array}{c}\ldots \ldots . \\
29 \mathrm{r} .4 \\
\cdots \cdots \\
\cdots \cdots\end{array}$ \\
\hline $\begin{array}{l}\text { No. } 3 \text { : } \\
50 \text { stalks, average length } \\
6 \mathrm{I} .4 \mathrm{~cm} ., 40 \text { heads; normal } \\
\text { development of roots to } \\
\text { I.5 feet; then very abun- } \\
\text { dant and evenly distributed } \\
\text { to } 2 \text { feet, below which prac- } \\
\text { tically none occurred }\end{array}$ & $\begin{array}{l}0-I \\
I-I \cdot 5 \\
1 \cdot 5^{-2} \\
2-2 \cdot 5\end{array}$ & $\begin{array}{l}22.5 \\
25.3 \\
25.2 \\
23.2\end{array}$ & $\begin{array}{l}\text { I I .8 } \\
\text { I8.0 } \\
\text { I7.8 } \\
23.2\end{array}$ & $\begin{array}{r}\text { I0.7 } \\
7.3 \\
7.4 \\
0.0\end{array}$ & $\mid \begin{array}{c}\cdots \\
\cdots \\
\cdots \\
\text { II.I } \\
\cdots\end{array}$ & 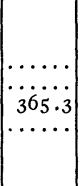 & $\mid \begin{array}{c}\cdots \cdots \\
\cdots \cdots \\
25.8 \\
\cdots \cdots\end{array}$ & $\left|\begin{array}{c}\cdots \cdots \\
\cdots \ldots 2 . \\
402.2 \\
\cdots \cdots\end{array}\right|$ & 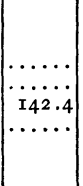 & $\mid \begin{array}{c}\ldots \ldots \\
\cdots \ldots . \\
259.8 \\
\cdots \cdots\end{array}$ \\
\hline $\left.\begin{array}{l}\text { No. } 4 \text { : } \\
36 \text { stalks, average length } \\
80.9 \mathrm{~cm} ., 36 \text { heads; roots } \\
\text { abundant and evenly dis- } \\
\text { tributed to } 2 \text { feet, below } \\
\text { which abundant but not } \\
\text { uniformly distributed }\end{array}\right\}$ & $\begin{array}{l}O-I \\
I-I \cdot 5 \\
1 \cdot 5-2 \\
2-2 \cdot 5\end{array}$ & $\begin{array}{l}23.4 \\
25.4 \\
23.7 \\
25.7\end{array}$ & $\begin{array}{l}12.2 \\
16.4 \\
17.9 \\
20.0\end{array}$ & $\begin{array}{r}\text { II.2 } \\
9.0 \\
5.8 \\
5.7\end{array}$ & $\begin{array}{l}\cdots \\
\ldots \\
\cdots \\
\ldots \\
\text { II. }\end{array}$ & 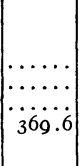 & $\begin{array}{c}\cdots \ldots \\
\cdots \cdots \\
\cdots \cdots \\
24 \cdot 5\end{array}$ & $\mid \begin{array}{c}\cdots \cdots \\
\cdots \cdots \cdots \\
405 \cdot 2\end{array}$ & $\mid \begin{array}{cc}\cdots & \cdots \\
\cdots & \cdots \\
\cdots & \cdots \\
270 & \\
\cdots & \end{array}$ & $\begin{array}{c}\cdots \cdots \\
\cdots \cdots \\
\cdots \\
134 \cdot 3 \\
34 \cdot 3\end{array}$ \\
\hline $\begin{array}{l}\text { No. 5: } \\
70 \text { stalks, average length } \\
50.7 \mathrm{~cm} ., 47 \text { heads; roots } \\
\text { very abundant, profusely } \\
\text { branched, uniformly dis- } \\
\text { tributed to } \mathbf{1} .5 \text { feet; few } \\
\text { below this level and none } \\
\text { beyond I.8 feet }\end{array}$ & $\begin{array}{l}O-I \\
I-I \cdot 5 \\
1 \cdot 5^{-2} \\
2-2 \cdot 5\end{array}$ & $\begin{array}{l}23.9 \\
24.3 \\
26.2 \\
23.4\end{array}$ & $\begin{array}{l}\text { II } .9 \\
17.4 \\
22.3 \\
22.9\end{array}$ & $\begin{array}{r}\text { I2.0 } \\
0.9 \\
3.9 \\
0.5\end{array}$ & $\begin{array}{c}99.5 \\
11.1 \\
\cdots \cdots \cdots \\
\cdots \cdots\end{array}$ & $\begin{array}{c}36 \mathrm{r} \cdot 5 \\
36 \mathbf{r} .8 \\
\cdots \cdots \\
\cdots \cdots\end{array}$ & $\begin{array}{c}70.7 \\
24.9 \\
\cdots \cdots \\
\cdots \cdots\end{array}$ & $\begin{array}{c}531.7 \\
397.8 \\
\cdots \cdots \\
\cdots \cdots\end{array}$ & $\mid \begin{array}{c}179.9 \\
222.3 \\
\cdots \cdots \\
\cdots \cdots \\
\cdots \cdots\end{array}$ & $\begin{array}{r}35 \mathrm{I} .8 \\
\mathrm{I} 75.5 \\
\cdots \cdots \cdots \\
\cdots \cdots\end{array}$ \\
\hline $\begin{array}{l}\text { No. } 6 \text { : } \\
65 \text { stalks, average length } \\
49 \text { cm., } 4 \mathrm{I} \text { heads; roots } \\
\text { well developed to } \mathrm{I} .5 \text { feet, } \\
\text { fairly abundant and ex- } \\
\text { ceptionally well branched } \\
\text { at } \mathrm{I} \cdot 5^{-2} \text { feet, none deeper }\end{array}$ & $\begin{array}{l}0-I \\
I-I \cdot 5 \\
I \cdot 5^{-2} \\
2-2 \cdot 5\end{array}$ & $\begin{array}{l}23.1 \\
25.0 \\
25.4 \\
22.9\end{array}$ & $\begin{array}{l}\text { I I. } 3 \\
\text { I } 6.6 \\
22.2 \\
22.5\end{array}$ & $\begin{array}{r}\text { I I . } 8 \\
8.4 \\
3.2 \\
0.4\end{array}$ & $\mid \begin{array}{c}99.5 \\
\ldots \ldots . \\
\text { II. I } \\
\cdots \ldots . .\end{array}$ & $\begin{array}{c}364 \cdot 7 \\
\cdots \cdots \cdot \\
378 \cdot 4 \\
\cdots \cdots \cdot\end{array}$ & $\begin{array}{c}70.7 \\
\ldots \ldots .8 \\
25.8 \\
\cdots \cdots\end{array}$ & $\begin{array}{r}534 \cdot 9 \\
\cdots \ldots \cdots \\
415 \cdot 3 \\
\cdots \cdots\end{array}$ & $\mid \begin{array}{r}r 33.4 \\
\cdots \cdots \\
6.7 \\
\cdots \cdots\end{array}$ & $\begin{array}{r}401 \cdot 5 \\
\ldots \ldots .6 \\
345.6 \\
\cdots \cdots\end{array}$ \\
\hline $\begin{array}{l}\text { No. } 7 \text { : } \\
7 \text { I stalks, average length } \\
53.6 \mathrm{~cm} ., 49 \text { heads; roots } \\
\text { very abundant, uniformly } \\
\text { distributed to I.5 feet, } \\
\text { fairly abundant to } 2 \text { feet, } \\
\text { not exceptionally abun- } \\
\text { dant below } 2 \text { feet but ex- } \\
\text { ceedingly well branched }\end{array}$ & $\begin{array}{l}0-1 \\
1-1 \cdot 5 \\
1 \cdot 5^{-2} \\
2-2 \cdot 5\end{array}$ & $\begin{array}{l}23.7 \\
24.6 \\
25.0 \\
29.8\end{array}$ & $\begin{array}{l}\text { II.6 } \\
\text { I6.5 } \\
\text { I } 8.3 \\
24.9\end{array}$ & $\begin{array}{r}\text { I2.I } \\
8.1 \\
6.7 \\
4.9\end{array}$ & $\begin{array}{c}99.5 \\
\ldots \ldots \ldots \\
\ldots \ldots \ldots \\
\text { II.I }\end{array}$ & $\begin{array}{c}363 \cdot 5 \\
\cdots \cdots \\
\cdots \cdots \\
378 \cdot 7\end{array}$ & $\begin{array}{l}70.7 \\
\ldots \ldots . \\
\ldots \ldots \\
24.5\end{array}$ & \begin{tabular}{r}
533.7 \\
$\cdots \cdots$ \\
\hdashline$\ldots .$. \\
414.3
\end{tabular} & 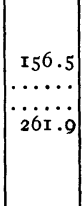 & $\begin{array}{l}377.2 \\
\cdots \cdots \cdots \\
\cdots \cdots \cdots \\
\mathbf{r}_{52.4}\end{array}$ \\
\hline $\left.\begin{array}{l}\text { Container without crop to } \\
\text { determine nitrification and } \\
\text { denitrification }\end{array}\right\}$ & $\begin{array}{l}O-I \\
I-I \cdot 5 \\
I \cdot 5^{-2} \\
2-2 \cdot 5\end{array}$ & $\begin{array}{l}25 \cdot 0 \\
25 \cdot 3 \\
25 \cdot 7 \\
25 \cdot 4\end{array}$ & $\begin{array}{l}23.9 \\
25.2 \\
24.4 \\
26.0\end{array}$ & $\begin{array}{r}\mathbf{I} .1 \\
0.1 \\
\mathbf{I} \cdot 3 \\
+0.6\end{array}$ & $\begin{array}{r}26.6 \\
8.8 \\
22.1 \\
8.8\end{array}$ & $\begin{array}{l}\cdots \cdots \\
\cdots \cdots \\
\cdots \cdots \\
\end{array}$ & $\begin{array}{l}70.7 \\
24 \cdot 9 \\
25.8 \\
24 \cdot 5\end{array}$ & $\begin{array}{l}97 \cdot 3 \\
33 \cdot 7 \\
47 \cdot 9 \\
33 \cdot 3\end{array}$ & $\begin{array}{l}97 \cdot 3 \\
33 \cdot 7 \\
47 \cdot 9 \\
33 \cdot 3\end{array}$ & $\begin{array}{l}\cdots \cdots \\
\cdots \cdots \\
\cdots \cdots \\
\cdots \cdots\end{array}$ \\
\hline
\end{tabular}


TABLE II-Continued

\begin{tabular}{|c|c|c|c|c|c|c|c|c|c|c|}
\hline \multirow[b]{2}{*}{$\begin{array}{l}\text { CONTAINER AND CROP } \\
\text { DEVELOPMENT }\end{array}$} & \multirow[b]{2}{*}{\begin{tabular}{|c|} 
DEPTH \\
IN \\
FEET
\end{tabular}} & \multicolumn{3}{|c|}{ WATER CONTENT } & \multicolumn{6}{|c|}{ NITRATE (NO 3 ) PARTS PER MILLION } \\
\hline & & $\begin{array}{c}\text { April } 7 \\
\text { (per } \\
\text { cent) }\end{array}$ & $\begin{array}{l}\text { June } \\
26 \\
\text { (per } \\
\text { cent) }\end{array}$ & $\begin{array}{l}\text { Loss } \\
\text { (per } \\
\text { cent) }\end{array}$ & $\begin{array}{c}\text { Origi- } \\
\text { nal } \\
\text { con- } \\
\text { tent } \\
\text { April } 7\end{array}$ & $\begin{array}{c}\text { Im- } \\
\text { preg- } \\
\text { nation } \\
\text { April } 7\end{array}$ & $\begin{array}{c}\text { Gain } \\
\text { by } \\
\text { nitri- } \\
\text { fica- } \\
\text { tion }\end{array}$ & Total & $\underset{26}{\text { June }}$ & Loss \\
\hline $\begin{array}{l}\text { No. I5: } \\
56 \text { stalks, average length } \\
6 \text { o.I cm., } 4 \text { I heads; normal } \\
\text { development of roots to } 2 \\
\text { feet; fewer roots deeper } \\
\text { but some reached } 2.5 \text { feet } \\
\text { and ran along bottom of } \\
\text { container }\end{array}$ & $\begin{array}{l}O-I \\
I-I \cdot 5 \\
I \cdot 5^{-2} \\
2-2 \cdot 5\end{array}$ & $\begin{array}{l}24 \cdot 2 \\
24 \cdot 9 \\
24.8 \\
27 \cdot 4\end{array}$ & $\begin{array}{l}\text { I I .7 } \\
\text { I6.8 } \\
\text { I7.8 } \\
2 \mathbf{I} .7\end{array}$ & $\begin{array}{r}\text { I } 2.5 \\
8.1 \\
7.0 \\
5.7\end{array}$ & \multicolumn{6}{|c|}{ Unfertilized } \\
\hline $\begin{array}{l}\text { No. I6: } \\
43 \text { stalks, average length } \\
70.0 \mathrm{~cm} ., 38 \text { heads; roots } \\
\text { very abundant in first } 2 \\
\text { feet; fewer below, but ex- } \\
\text { tended to } 2.5 \text { feet }\end{array}$ & $\begin{array}{l}O-I \\
I-I \cdot 5 \\
I \cdot 5-2 \\
2-2 \cdot 5\end{array}$ & $\begin{array}{l}24.3 \\
23.9 \\
23.9 \\
27.6\end{array}$ & $\begin{array}{l}\text { I2.0 } \\
\text { I6.9 } \\
\text { I6. } 4 \\
21.0\end{array}$ & $\begin{array}{r}\text { I } 2.3 \\
7.0 \\
7.5 \\
6.6\end{array}$ & \multicolumn{6}{|c|}{ Unfertilized } \\
\hline $\begin{array}{l}\text { No. I7: } \\
43 \text { stalks, average length } \\
72.7 \mathrm{~cm} ., 38 \text { heads; roots } \\
\text { very abundant to } 2 \text { feet, } \\
\text { and fairly abundant to } \\
\text { bottom of container }\end{array}$ & $\begin{array}{l}O-I \\
I-I \cdot 5 \\
I \cdot 5^{-2} \\
2-2 \cdot 5\end{array}$ & $\begin{array}{l}24.6 \\
22.6 \\
23.8 \\
27.3\end{array}$ & $\begin{array}{l}\text { Ir .2 } \\
\text { I } 4.7 \\
\text { I } 7.8 \\
23.2\end{array}$ & $\begin{array}{r}\text { I3.4 } \\
7.9 \\
6.0 \\
4 . I\end{array}$ & \multicolumn{6}{|c|}{ Unfertilized } \\
\hline
\end{tabular}

rapid ripening of the crop, due to abnormal weather conditions, water was absorbed in considerable quantities (3-I3 per cent of dry weight of soil) at all depths to which the roots penetrated. The large amounts of nitrates removed at the several levels are indicated by numbers representing parts per million opposite these levels in fig. 3. When the fertilizer was placed both in the surface foot and at I-I.5, I.5-2, and $2-2.5$ feet respectively, the amounts removed were, in order, $14.0,61.5$, and 14.5 per cent greater than when the fertilizer was placed in the surface foot alone.

The number of stalks developing from the 30 original plants in each container decreased progressively with the depth of the fertilizer from 60 to 36 (fig. 3). Except when the nitrates were below 2 feet, the number of stalks was greater than that of the average of the controls. In the doubly fertilized series the number varied from 65 to $7 \mathrm{I}$, which was $38-5 \mathrm{I}$ per cent greater than the average of the controls, and 8-I8 per cent greater than when the fertilizer was placed in the surface foot only.

The average length of stalk increased progressively as the fertilizer was more deeply placed, ranging from 54.5 to $80.9 \mathrm{~cm}$. (fig. 3). Except when the nitrates were below 2 feet in depth, the 
stalks averaged shorter than those of the controls. In the doubly fertilized series the stalks were not only shorter than those of any of the controls, but also shorter than those of any of the singly fertilized series.

The number of heads was greater in every container (except no. 4) than the average of the controls. Where double fertilization obtained, the number exceeded that of the controls by $5^{-26}$ per cent. This statement may be misleading, however, unless the differences in the total number of stalks are taken into account. Column 7 of table III gives the percentage of stalks bearing heads, and shows that in every container (except no. 4 , where the fertilizer

TABLE III

Number AND LENGTH OF STALKS AND heADS IN NITRATE SERIES

\begin{tabular}{|c|c|c|c|c|c|c|}
\hline Container & $\begin{array}{c}\text { Depth of fertilizer } \\
\text { (feet) }\end{array}$ & $\begin{array}{l}\text { Number of } \\
\text { stalks }\end{array}$ & $\begin{array}{l}\text { Average } \\
\text { length of } \\
\text { stalks } \\
\text { (cm.) }\end{array}$ & $\begin{array}{l}\text { Number of } \\
\text { heads }\end{array}$ & $\begin{array}{l}\text { Average } \\
\text { length of } \\
\text { heads } \\
\text { (cm.) }\end{array}$ & $\begin{array}{c}\text { Stalks } \\
\text { bearing } \\
\text { heads } \\
\text { (per cent) }\end{array}$ \\
\hline I . . & O. I & 60 & 54.5 & 42 & 6.9 & 70 \\
\hline $2 .$. & $\mathrm{I}-\mathrm{I} \cdot 5$ & 57 & 58.6 & 43 & 6.7 & 75 \\
\hline $3 \ldots \ldots$ & I. $5^{-2}$ & 50 & $6 \mathrm{I} .4$ & 40 & $6 . I$ & 80 \\
\hline $4 \ldots$ & $2-2 \cdot 5$ & 36 & 80.9 & 36 & 6.4 & 100 \\
\hline $5 \ldots$ & $O-I$ and $I-I .5$ & 70 & 50.7 & 47 & 6.9 & 67 \\
\hline 6 & $0-1$ and $I .5^{-2}$ & 65 & 49.0 & $4 \mathrm{I}$ & $7 \cdot 3$ & 63 \\
\hline 7 . & $0-1$ and $2-2.5$ & $7 \mathrm{I}$ & 53.6 & 49 & 7.2 & 69 \\
\hline I5. & $\ldots \ldots \ldots \ldots$ & 56 & 60.1 & $4 \mathrm{I}$ & 6.7 & 73 \\
\hline I6. & $\ldots \ldots \ldots \ldots \ldots$ & 43 & 70.0 & 38 & 6.4 & 90 \\
\hline I $7 \ldots$ & $\ldots$ & 43 & 72.7 & 38 & 6.4 & 90 \\
\hline
\end{tabular}

was at $2-2.5$ feet and was reached at a later period) a smaller percentage of stalks bore heads, and that the smallest percentages are associated with the doubly fertilized soils. The heads in the doubly fertilized series were longest and exceeded the average of controls by $6-\mathrm{I} 2$ per cent.

The average total dry weight of the controls (86.9 gm.) was exceeded by 12.2 per cent when the fertilizer was added to the surface foot only (table IV), but when the fertilizer was placed at lower levels, a decrease of 5.9 , I 5.5, and 4.9 per cent was determined in containers 2, 3, and 4 respectively. Adding nitrates to other levels in addition to the first foot resulted in an increase in dry weight. This gain amounted to I I.5, I I.3, and 26.9 per cent over the average of the controls in containers 5,6 , and 7 respectively. 
The dry weight of the grain was decreased in every case where nitrate was applied either singly or doubly, except in container 7 . This decrease was no greater in the doubly fertilized than in the singly fertilized series, nor is there any definite relation between the depth of the fertilizer and the depression in yield of grain.

The dry weight of straw was increased in container I of the singly fertilized series 24.9 per cent over the average of the controls, but where the nitrate was placed deeper than the first foot, a decrease occurred. The dry weight was equal to that of each of two of the controls, however, where the salt was at I-I.5 and at $2-2.5$ feet. The increases in the doubly fertilized soils were very

TABLE IV

DRY WEIGHT AND NITROGEN CONTENT OF GRAIN AND STRAW

\begin{tabular}{|c|c|c|c|c|c|c|c|}
\hline Container & $\begin{array}{l}\text { Depth of fertilizer } \\
\text { (feet) }\end{array}$ & $\begin{array}{c}\text { Dry weight } \\
\text { of straw } \\
\text { (gm.) }\end{array}$ & $\begin{array}{l}\text { Dry weight } \\
\text { of grain } \\
\text { (gm.) }\end{array}$ & $\begin{array}{l}\text { Total dry } \\
\text { weight of } \\
\text { tops } \\
\text { (gm.) }\end{array}$ & $\begin{array}{l}\text { Ratio of } \\
\text { grain to } \\
\text { straw }\end{array}$ & $\begin{array}{l}\text { Nitrogen } \\
\text { content of } \\
\text { grain } \\
\text { (per cent) }\end{array}$ & $\begin{array}{l}\text { Nitrogen } \\
\text { content of } \\
\text { straw } \\
\text { (per cent) }\end{array}$ \\
\hline r...... & O. I & $67 . \mathrm{I}$ & 30.4 & 97.5 & 0.45 & 3.19 & $2.0 \mathrm{I}$ \\
\hline $2 \ldots \ldots \ldots$ & $\mathrm{I}-\mathrm{I} .5$ & 52.9 & 28.9 & 81.8 & 0.55 & $3 \cdot 30$ & I. 42 \\
\hline $3 \ldots \ldots \ldots$ & I. $5^{-2}$ & 46.3 & $27 . \mathrm{I}$ & 73.4 & 0.59 & 2.52 & 0.99 \\
\hline $4 \ldots \ldots \ldots$ & $2-2.5$ & $5 \mathrm{I} . \mathrm{I}$ & 3 I. 5 & 82.6 & 0.62 & 2.53 & 0.82 \\
\hline $5 \ldots \ldots \ldots$ & $O-I$ and $I-I .5$ & 68.7 & 26.2 & 96.9 & $0.4 \mathrm{I}$ & $3 \cdot 39$ & I. 92 \\
\hline $6 \ldots$ & $0^{-1}$ and $\mathrm{I} \cdot 5^{-2}$ & 68.7 & 28.0 & 96.7 & $0.4 \mathrm{I}$ & $3.4 \mathrm{I}$ & I. 82 \\
\hline $7 \ldots$ & $0-1$ and $2-2.5$ & 75.6 & 34.7 & IIO. 3 & 0.46 & $3 \cdot 38$ & 2.02 \\
\hline I5 $\ldots$ & None & 58.7 & 33.4 & 92. I & 0.57 & 2.79 & 0.86 \\
\hline I6.. & None & 51.2 & 31.6 & 82.8 & 0.62 & 2.47 & 0.66 \\
\hline I $7 \ldots \ldots$ & None & 5 I. 3 & 34.7 & 86.0 & 0.68 & 2.33 & 0.55 \\
\hline
\end{tabular}

marked in every instance, being $27.9,27.9$, and 40.8 per cent in containers 5, 6, and 7 respectively. Furthermore, the increase in the doubly fertilized series over that of the crop where the soil was fertilized only in the surface foot was $2.4^{-1} 2.7$ per cent.

The application of nitrogen fertilizer caused reduction of grain in proportion to straw. From the data in column 6, table IV, it may be seen that the ratio of grain to straw is lower than the average of the controls in any container in which the crop was fertilized. The ratio increased as the amount of nitrate absorbed decreased. Thus it rose from 0.45 , when the nitrates were in the surface foot, progressively to 0.62 , when the nitrates were at a depth of 2.5 feet. It was less in the doubly fertilized series (except in container 7) than when the nitrate was added to the surface foot only. 
A comparison of the data on the nitrogen content of grain and straw given in table IV shows that (I) the average nitrogen content of the grain of the controls (2.53 per cent) was exceeded by that of the crop from the singly fertilized series by 26.1 and 30.4 per cent respectively, when the fertilizer was at depths of $\mathbf{O}^{-I}$ and $\mathbf{I}^{-} \mathrm{I} .5$ feet; (2) in the doubly fertilized soils the greater nitrogen content of the grain over the average of the controls was $34,34.8$, and 33.6 per cent respectively, as the salt was progressively deeper. Moreover, only one of the controls exceeded in nitrogen content of grain any individual of either of the two fertilized series. The grain from container 15 analyzed higher than that from containers 3 and 4 . The average nitrogen content of the straw of the controls ( 0.69 per cent) was exceeded in every case by that of the fertilized plants. Moreover, any one of the controls had a much lower nitrogen content of straw than any crop in the fertilized series, except where the nitrate was below two feet. The increases, in sequence from containers I to 4 , were I9I.3, I05.8, 43.5, and I8.8 per cent, and for the doubly fertilized series ( 5 to 7 ) I 78.2, I63.7, and 192.7 per cent.

\section{PHOSPHORUS SERIES}

The experiment with phosphorus fertilizer was identical with that of the nitrogen series as regards number of containers, position of seals, impregnated soil layers, etc., and the same control crops were used for comparison. The growth of the tops and roots, together with the amounts of water removed at the several levels, is shown in table V. A comparison of this table with fig. 4 shows the root activities at all depths, water being absorbed in quantities similar to those removed by plants of the nitrate series.

Data on the number and length of stalks and heads in the several containers are given in table VI. The number of stalks and the length of heads were less than the average of the controls in every case where fertilizer was used, except in the first container. Moreover, with the exception of container 2, the stalks were shorter and the heads fewer, but the percentage of stalks bearing heads was nearly equal to or greater than that of the average of the controls. In the containers where the soil was fertilized at two levels the stalks averaged fewer, and the heads were fewer and shorter than when 
phosphorus was placed in a single layer. With one exception, however, the percentage of stalks bearing heads was greater in the doubly fertilized series.

TABLE V

Loss of WATER From phosphorus SERIES AND CONTROLS April 7 to JUNE 24

\begin{tabular}{|c|c|c|c|c|c|}
\hline \multirow[b]{2}{*}{ CONTAINER AND CROP DEVELOPMENT } & \multirow[b]{2}{*}{$\begin{array}{c}\text { DEPTH } \\
\text { IN FEET }\end{array}$} & \multicolumn{3}{|c|}{ WATER CONTENT } & \multirow[b]{2}{*}{$\begin{array}{l}\text { PosITION OF } \\
\text { FERTILIZER } \\
\text { (feet) }\end{array}$} \\
\hline & & $\begin{array}{l}\text { April } 7 \\
\text { (per } \\
\text { cent) }\end{array}$ & $\begin{array}{c}\text { June } 24 \\
\text { (per } \\
\text { cent) }\end{array}$ & $\begin{array}{l}\text { Loss } \\
\text { (per } \\
\text { cent) }\end{array}$ & \\
\hline $\begin{array}{l}\text { No. I: } 48 \text { stalks, average length } 59.1 \mathrm{~cm} ., 38 \\
\text { heads; roots as abundant as in other unfertil- } \\
\text { ized first foot of soil; below I foot less abun- } \\
\text { dant than usual but extending to } 2.5 \text { feet }\end{array}$ & $\begin{array}{l}0-1 \\
I-I \cdot 5 \\
I \cdot 5^{-2} \\
2-2 \cdot 5\end{array}$ & $\begin{array}{l}2 \mathrm{I} \cdot 9 \\
23 . \mathrm{I} \\
24.8 \\
28.1\end{array}$ & $\begin{array}{l}\text { I0.9 } \\
\text { I7.8 } \\
\text { I9.9 } \\
25.5\end{array}$ & $\left.\begin{array}{r}\text { II.0 } \\
5 \cdot 3 \\
4.9 \\
2.6\end{array}\right\}$ & $0-1$ \\
\hline $\begin{array}{l}\text { No. } 2: 4 \text { stalks, average length } 69.5 \mathrm{~cm} ., 39 \\
\text { heads; roots fairly abundant in first I.5 feet, } \\
\text { below which much fewer but some extended } \\
\text { to } 2.5 \text { feet }\end{array}$ & $\begin{array}{l}0-I \\
I-I \cdot 5 \\
I \cdot 5^{-2} \\
2-2 \cdot 5\end{array}$ & $\begin{array}{l}23 \cdot 9 \\
25 \cdot 3 \\
23 \cdot 5 \\
25 \cdot 0\end{array}$ & $\begin{array}{l}\text { II . } 9 \\
20.4 \\
2 \text { I.I } \\
23.2\end{array}$ & $\left.\begin{array}{r}\text { I } 2.0 \\
4.9 \\
2.4 \\
1.8\end{array}\right\}$ & $I-I \cdot 5$ \\
\hline $\begin{array}{l}\text { No. } 3: 40 \text { stalks, average length } 63.8 \mathrm{~cm} ., 3.3 \\
\text { heads; roots very abundant, well distributed } \\
\text { to I.5 feet; fairly abundant to } 2 \text { feet, but } \\
\text { sparse } 2-2.5 \text { feet }\end{array}$ & $\begin{array}{l}0-I \\
I-I \cdot 5 \\
I \cdot 5^{-2} \\
2-2 \cdot 5\end{array}$ & $\begin{array}{l}27.0 \\
24.8 \\
22.4 \\
25.8\end{array}$ & $\begin{array}{l}\text { II.6 } \\
\text { I7.3 } \\
\text { I9.6 } \\
24.2\end{array}$ & $\left.\begin{array}{r}\mathrm{I} .4 \\
7.5 \\
2.8 \\
\mathrm{I} .6\end{array}\right\}$ & $\mathrm{I} \cdot 5^{-2}$ \\
\hline $\left.\begin{array}{l}\text { No. } 4: 45 \text { stalks, average length } 56.3 \mathrm{~cm} ., 37 \\
\text { heads; roots very abundant in first foot and } \\
\text { more abundant to } 2 \text { feet than in any container } \\
\text { of series; fairly abundant at } 2-2.5 \text { feet }\end{array}\right\}$ & $\begin{array}{l}O-I \\
I \rightarrow I .5 \\
I .5^{-2} \\
2-2 \cdot 5\end{array}$ & $\begin{array}{l}24 \cdot 2 \\
23 \cdot 0 \\
23 \cdot 3 \\
28.3\end{array}$ & $\begin{array}{l}\text { I2.2 } \\
\text { I3.6 } \\
\text { I8.0 } \\
23.6\end{array}$ & $\left.\begin{array}{r}12 \cdot 0 \\
9 \cdot 4 \\
5 \cdot 3 \\
4 \cdot 7\end{array}\right\}$ & $2-2 \cdot 5$ \\
\hline $\begin{array}{l}\text { No. } 5: 4 \mathrm{I} \text { stalks, average length } 59.3 \mathrm{~cm} ., 35 \\
\text { heads; roots very abundant, evenly dis- } \\
\text { tributed to I.5 feet; very few found deeper, } \\
\text { single root penetrated to } 2.5 \text { feet }\end{array}$ & $\begin{array}{l}O-I \\
I-I \cdot 5 \\
I \cdot 5-2 \\
2-2 \cdot 5\end{array}$ & $\begin{array}{l}25 \cdot I \\
24 \cdot I \\
23 \cdot 3 \\
25 \cdot 2\end{array}$ & $\begin{array}{l}\text { I2.9 } \\
20.0 \\
21 . I \\
24.1\end{array}$ & $\left.\begin{array}{r}\mathrm{I} 2.2 \\
4 . \mathrm{I} \\
2.2 \\
\mathrm{I} . \mathrm{I}\end{array}\right\}$ & $O-I$ and $I-I \cdot 5$ \\
\hline $\begin{array}{l}\text { No. } 6: 38 \text { stalks, average length } 63.7 \mathrm{~cm} ., 33 \\
\text { heads; roots very abundant, uniformly dis- } \\
\text { tributed to } 2 \text { feet, scarce in } 2-2.5 \text { foot layer ex- } \\
\text { cept in center where they penetrated to } 2.4 \text { feet }\end{array}$ & $\begin{array}{l}0-I \\
I-I \cdot 5 \\
I \cdot 5^{-2} \\
2-2 \cdot 5\end{array}$ & $\begin{array}{l}26.5 \\
29.0 \\
24.1 \\
25.6\end{array}$ & $\begin{array}{l}\text { II } .9 \\
\text { I9.0 } \\
\text { I6.0 } \\
24 \cdot 3\end{array}$ & $\left.\begin{array}{r}\text { I4.6 } \\
\text { I0.0 } \\
8.1 \\
1.3\end{array}\right\}$ & $0-1$ and $I \cdot 5^{-2}$ \\
\hline $\begin{array}{l}\text { No. } 7: 3 \text { I stalks, average length } 60.9 \mathrm{~cm} ., 28 \\
\text { heads; roots abundant, rather evenly dis- } \\
\text { tributed to I.5 feet, slightly fewer to } 2 \text { feet, } \\
\text { below which none found }\end{array}$ & $\begin{array}{l}0-I \\
I-I \cdot 5 \\
I \cdot 5-2 \\
2-2 \cdot 5\end{array}$ & $\begin{array}{l}24 \cdot 4 \\
26.2 \\
25 \cdot 2 \\
23.6\end{array}$ & $\begin{array}{l}\text { II } .8 \\
\text { I9.I } \\
20.9 \\
23.0\end{array}$ & $\left.\begin{array}{r}12.6 \\
7.1 \\
4 \cdot 3 \\
0.6\end{array}\right\}$ & $0-1$ and $2-2.5$ \\
\hline $\begin{array}{l}\text { No. }{ }_{5}: 56 \text { stalks, average length } 60 . \mathrm{cm} ., 4 \mathrm{I} \\
\text { heads; normal development of roots to } 2 \text { feet; } \\
\text { fewer deeper but some reached } 2.5 \text { feet and } \\
\text { ran along bottom of container }\end{array}$ & $\begin{array}{l}0-\mathrm{I} \\
\mathrm{I}-\mathrm{I} \cdot 5 \\
\mathrm{I} \cdot 5^{-2} \\
2-2 \cdot 5\end{array}$ & $\begin{array}{l}24.2 \\
24 \cdot 9 \\
24.8 \\
27 \cdot 4\end{array}$ & $\begin{array}{l}\text { II.7 } \\
\text { I6.8 } \\
\text { I } 7.8 \\
21.7\end{array}$ & $\left.\begin{array}{r}12 \cdot 5 \\
8.1 \\
7.0 \\
5 \cdot 7\end{array}\right\}$ & None \\
\hline $\left.\begin{array}{l}\text { No. I6: } 43 \text { stalks, average length } 70.0 \mathrm{~cm} ., 38 \\
\text { heads; roots very abundant in first } 2 \text { feet of } \\
\text { soil; fewer below but extending to } 2.5 \text { feet }\end{array}\right\}$ & $\begin{array}{l}O-I \\
I-I \cdot 5 \\
I \cdot 5^{-2} \\
2-2 \cdot 5\end{array}$ & $\begin{array}{l}24 \cdot 3 \\
23 \cdot 9 \\
23 \cdot 9 \\
27 \cdot 6\end{array}$ & $\begin{array}{l}\text { I2.0 } \\
\text { I6.9 } \\
\text { I6.4 } \\
21.0\end{array}$ & $\left.\begin{array}{r}12.3 \\
7.0 \\
7.5 \\
6.6\end{array}\right\}$ & None \\
\hline $\left.\begin{array}{l}\text { No. I7: } 43 \text { stalks, average length } 72.7 \mathrm{~cm} ., 38 \\
\text { heads; roots very abundant to } 2 \text { feet and } \\
\text { fairly abundant to bottom of container }\end{array}\right\}$ & $\begin{array}{l}O-I \\
I-I \cdot 5 \\
I \cdot 5^{-2} \\
2-2 \cdot 5\end{array}$ & $\begin{array}{l}24.6 \\
22.6 \\
23.8 \\
27.3\end{array}$ & $\begin{array}{l}\text { II .2 } \\
\text { I } 4.7 \\
\text { I } 7.8 \\
23.2\end{array}$ & $\left.\begin{array}{r}\mathrm{r} 3.4 \\
7.9 \\
6.0 \\
4 . \mathrm{r}\end{array}\right\}$ & None \\
\hline
\end{tabular}

Table VII shows that the average total dry weight of the controls $(87.0 \mathrm{gm}$.) exceeded that of any of the crops where the soil was fertilized at any depth with phosphorus. In the singly fertilized soils, in the order of the increasing depth of the fertilizer, the 
decreases were II.3, I8.I, 24.7 , and 23.7 per cent respectively. Where doubly fertilized the depression in yield was much greater, being, in the above order, 43.0, 36.6, and 51.6 per cent. These great decreases in dry weight occurred both in grain and straw. The depression of grain yield was somewhat greater than that of

TABLE VI

Number AND LENGTH OF STALKS AND heAdS IN PHOSPHORUS SERIES

\begin{tabular}{|c|c|c|c|c|c|c|}
\hline Container & $\begin{array}{c}\text { Depth of fertilizer } \\
\text { (feet) }\end{array}$ & $\begin{array}{l}\text { Number of } \\
\text { stalks }\end{array}$ & $\begin{array}{c}\text { Average } \\
\text { length } \\
\text { of stalks } \\
\text { (cm.) }\end{array}$ & $\begin{array}{l}\text { Number of } \\
\text { heads }\end{array}$ & $\begin{array}{l}\text { Average } \\
\text { length of } \\
\text { heads } \\
\text { (cm.) }\end{array}$ & $\begin{array}{c}\text { Stalks bearing } \\
\text { heads } \\
\text { (per cent) }\end{array}$ \\
\hline$I \ldots \ldots$ & $0-I$ & 48 & $59 . I$ & 38 & 6.5 & $79 . \mathrm{I}$ \\
\hline $2 \ldots \ldots$ & $\mathrm{I}-\mathrm{I} \cdot 5$ & $4 \mathrm{I}$ & $69 \cdot 5$ & 39 & $5 \cdot 5$ & $95 . \mathrm{I}$ \\
\hline $3 \ldots \ldots$ & I. $5^{-2}$ & 40 & 63.8 & 33 & 6.4 & $82 \cdot 5$ \\
\hline $4 \ldots \ldots$ & $2-2 \cdot 5$ & 45 & $56 \cdot 3$ & 37 & 6.0 & 82.2 \\
\hline $5 \cdot$ & $0-\mathrm{I}$ and $\mathrm{I}-\mathrm{I} \cdot 5$ & $4 \mathrm{I}$ & $59 \cdot 3$ & 35 & 4.6 & $85 \cdot 5$ \\
\hline $6 \ldots .$. & $O^{-I}$ and $I \cdot 5^{-2}$ & $3^{8}$ & 63.7 & 33 & $5 \cdot I$ & 86.8 \\
\hline $7 \ldots \ldots$ & $0-1$ and $2-2.5$ & $3 I$ & 60.9 & 28 & 5.2 & 90.3 \\
\hline I5. & Control & $5^{6}$ & 60.1 & $4 I$ & 6.7 & $73 \cdot 2$ \\
\hline I6. & Control & 43 & 70.0 & 38 & 6.4 & $88 \cdot 3$ \\
\hline $17 \ldots \ldots$ & Control & 43 & 72.7 & $3^{8}$ & 6.4 & 88.3 \\
\hline
\end{tabular}

TABLE VII

DRY WEIGHT AND PHOSPHORUS CONTENT OF GRAIN AND STRAW

\begin{tabular}{|c|c|c|c|c|c|c|c|}
\hline Container & $\begin{array}{c}\text { Depth of fertilizer } \\
\text { (feet) }\end{array}$ & $\begin{array}{c}\text { Dry weight } \\
\text { of straw } \\
\text { (gm.) }\end{array}$ & $\begin{array}{c}\text { Dry weight } \\
\text { of grain } \\
\text { (gm.) }\end{array}$ & $\begin{array}{l}\text { Total dry } \\
\text { weight of } \\
\text { tops } \\
\text { (gm.) }\end{array}$ & $\begin{array}{l}\text { Ratio of } \\
\text { grain to } \\
\text { straw }\end{array}$ & $\begin{array}{c}\text { Phosphorus } \\
\text { content of } \\
\text { grain } \\
\text { (per cent) }\end{array}$ & $\begin{array}{l}\text { Phosphorus } \\
\text { content of } \\
\text { straw } \\
\text { (per cent) }\end{array}$ \\
\hline I. . . & O. I & 48.9 & 28.2 & 77.1 & $0.5^{8}$ & I. 337 & 0.444 \\
\hline $2 \ldots \ldots$ & $\mathrm{I}-\mathrm{I} \cdot 5$ & $43 \cdot 9$ & $27 \cdot 3$ & 71.2 & 0.62 & I. 245 & 0.476 \\
\hline $3 \ldots \ldots$ & I. $5^{-2}$ & 40.8 & $24 \cdot 7$ & $65 \cdot 5$ & $0.6 I$ & I. 248 & 0.355 \\
\hline $4 \ldots \ldots$ & $2-2 \cdot 5$ & 40.5 & $25 \cdot 9$ & 66.4 & 0.64 & I. I 76 & 0.418 \\
\hline & $0-I$ and $I-I .5$ & 28.8 & 20.8 & 49.6 & 0.72 & I. 237 & 0.457 \\
\hline $6 \ldots$ & $O^{-I}$ and $I .5^{-2}$ & $33 \cdot 9$ & 2 I. 2 & $55 \cdot I$ & 0.63 & I. 237 & 0.706 \\
\hline $7 \ldots$ & $0-1$ and $2-2.5$ & $22 \cdot 5$ & I9. 6 & $42 . I$ & 0.87 & I. 250 & 0.533 \\
\hline I 5. & None & $5^{8.7}$ & $33 \cdot 4$ & $92 . I$ & 0.57 & I. 210 & o. 287 \\
\hline I6. & None & 5 I. 2 & 31.6 & 82.9 & 0.62 & I. I98 & 0.270 \\
\hline I $7 \ldots \ldots$ & None & $5^{\mathrm{I}} \cdot 3$ & $34 \cdot 7$ & 86. I & 0.68 & I. I79 & 0.347 \\
\hline
\end{tabular}

the straw when only one layer of soil was fertilized, but when a deeper layer in addition to the surface foot was impregnated, the depression of the straw yield was greater.

The ratio of grain to straw averaged 0.62 for the controls. In the singly fertilized series variations from this ratio were negligible, but in the doubly fertilized soils the ratio was considerably increased. 
Lack of consistent correlation of the ratios with the phosphorus content of either grain or straw, however, indicates that they probably have little significance. The average phosphorus content of grain of the controls (I.I96 per cent) was less than that from any container where the soil was singly fertilized above 2 feet. The increases, in the sequence of increasing depth of fertilizer, were Ir.8, 4.I, and 4.3 per cent. Where the phosphorus salt was below 2 feet a decrease of 1.7 per cent was determined. In the doubly fertilized soils the gains, in the above sequence, were 3.4, 3.4, and 4.5 per cent. Furthermore, with the single exception just noted, none of the three controls equaled in phosphorus content of grain that of any of the fertilized crops.

The increase of phosphorus content of straw over that of the controls, which averaged $0.30 \mathrm{I}$ per cent, was greater than that of the grain. Moreover, each control had a lower phosphorus content of straw than that of any crop regardless of the depth at which the fertilizer was present. In the singly fertilized series, in order of increasing depth of phosphorus salts, the percentages were 47.5 , 58.I, I 7.9, and 38.9 respectively. Using the same sequence in the doubly fertilized series, they were 5 I.8, I34.5, and 77.I per cent.

\section{Discussion}

The value of the data obtained from these experiments is enhanced by the fact that the crop was grown under field conditions and in containers sufficiently large to permit normal root development. Except for the effects brought about by the fertilizers, the crop developed normally. This was determined both by comparison with the controls and the crop in the field surrounding the containers. The effects of the various treatments of fertilizer became evident in the nitrogen series early in the development of the crop. Not only were the plants in contact with the nitrates more numerous, but also more bushy. They had longer and broader leaves, slightly thicker stems, and were a deeper green than either the controls or the plants fertilized with phosphorus. All of these characters were accentuated in the containers where nitrates occurred in the deeper soils as well as in the surface foot. Plants in contact with the phosphorus showed a decided glaucous appearance. 
These differences in the two series, when the crop was 53 days old, are shown in figs. 5 and 6 . The lateral spread of the tops of the plants on May 27 averaged 1o inches for the controls, 7.5 inches for the phosphorus series, and 13 inches for those fertilized with nitrates. The average greatest diameter of the second leaf from the top at this time was $\mathrm{I} 4.4 \mathrm{~mm}$. for the controls, and ${ }_{5} \mathrm{~mm}$. and $\mathrm{r} 8 \mathrm{~mm}$. respectively for the phosphorus and nitrate series. Head-

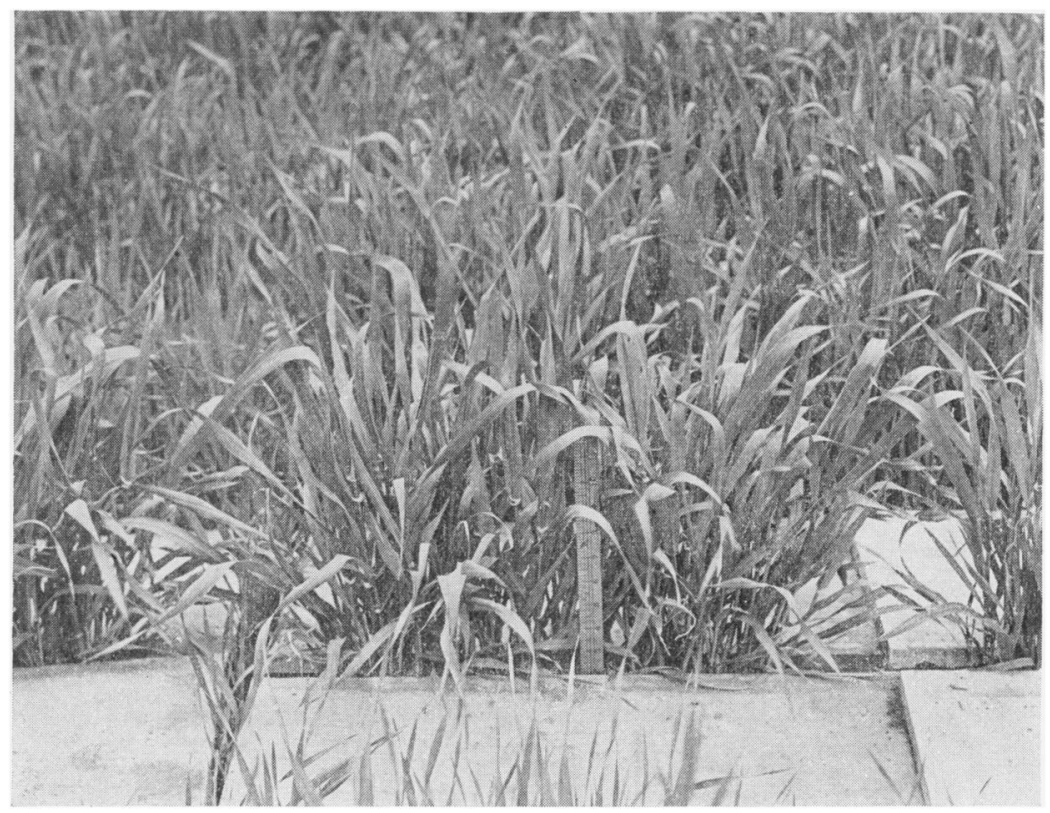

Fig. 5.-53-day old plants in container where soil was fertilized with nitrates at $0-1$ and $I-1.5$ feet.

ing occurred among the phosphorus fertilized plants on June I, slightly in advance of the controls, and 5 to 7 days earlier than in the nitrate series. The condition of the crop at the time of harvest (June 24), where the nitrate and phosphate respectively occurred at $\mathrm{I}-\mathrm{I} .5$ feet in depth, as well as that of a control, is shown in figs. 7-9.

The researches of Nobbe (I6), Thiel (I8), Höveler (II), Frank (5), MÜller-Thurgau (I5), von Seelhorst (I7), LivingSTON (I4), BRENCHLEY and JACKSON (I), and many others are in 
agreement that the presence of fertilizer increases root development. A greater development of the barley roots in the soil layers impregnated with the nitrate was found, but little or no difference was observed in the phosphorus series.

It is of interest that the roots absorbed nitrates at all levels into which they penetrated, notwithstanding the fact that the salt at all times was abundant in the surface soil. In fact, they extracted

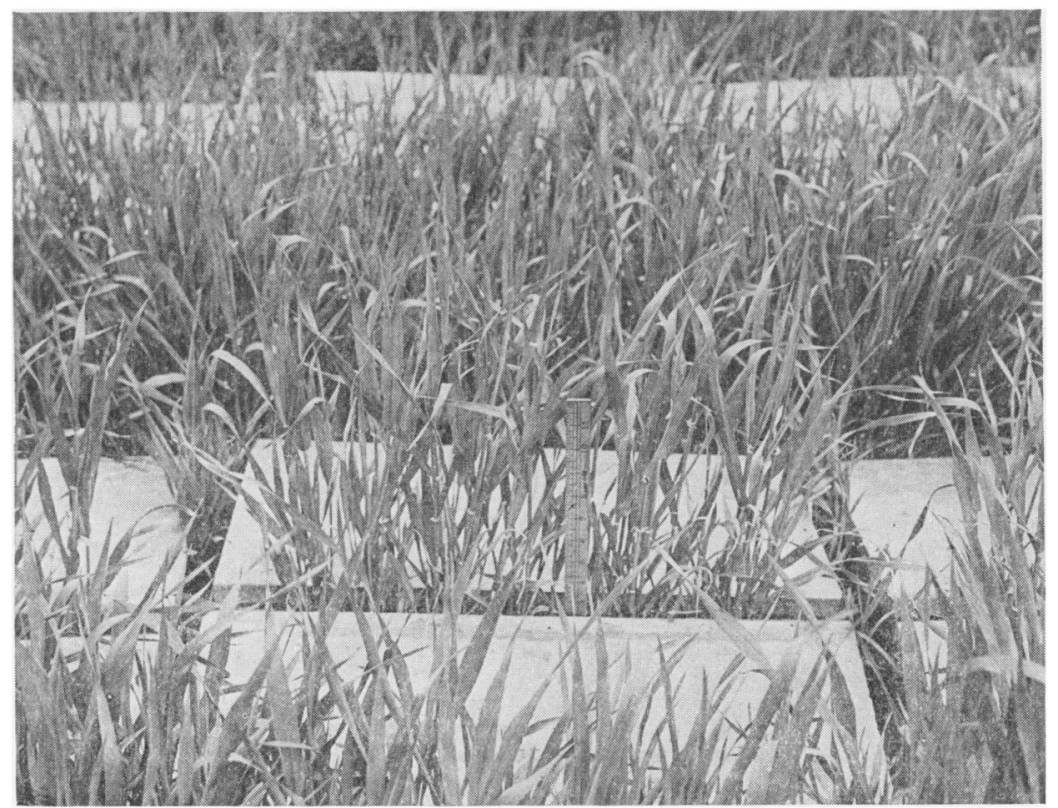

Fig. 6.-Soil fertilized with phosphorus at o-r foot

almost as much from the surface foot in addition to the supply obtained from the deeper soil as when nitrate was supplied to the surface foot alone. This shows that the presence of salts in the subsoil profoundly affects the amount of nitrate absorbed, and this in turn materially affects the growth of the crop and the quantity and quality of the yield. The amount of phosphorus absorbed from the several levels was not determined, but judging from the variations in the phosphorus content of the plants, these statements seem to hold equally true for phosphate fertilizers. 
Nitrates placed below but in conjunction with fertilizer in the surface foot failed to increase the nitrogen content of the straw beyond that of the crop fertilized in the surface foot only. In every instance, however, it resulted in an increased nitrogen content

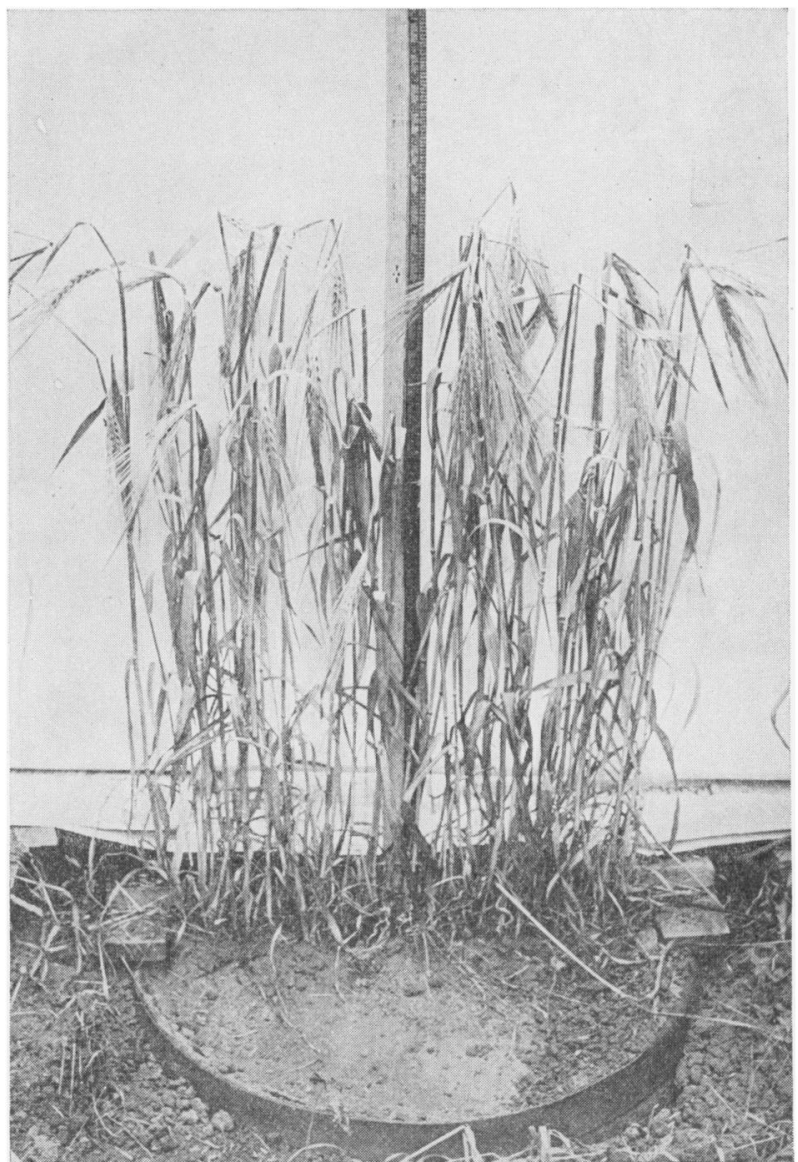

FIg. 7.-Mature crops: soil fertilized with nitrates

of the grain. Conversely, under similar conditions when phosphorus fertilizer was employed, while the phosphorus content of the grain was not raised, that of the straw was increased in every case. Since phosphorus placed below as well as in the surface foot gave a better quality of straw, while under the same conditions 
nitrogen caused a better quality of grain, it seems clear that when the limits of improvement in the quality of cereal crops through attention to the upper part of the soil have been reached, there are still possibilities of further progress through increased attention to the deeper strata.

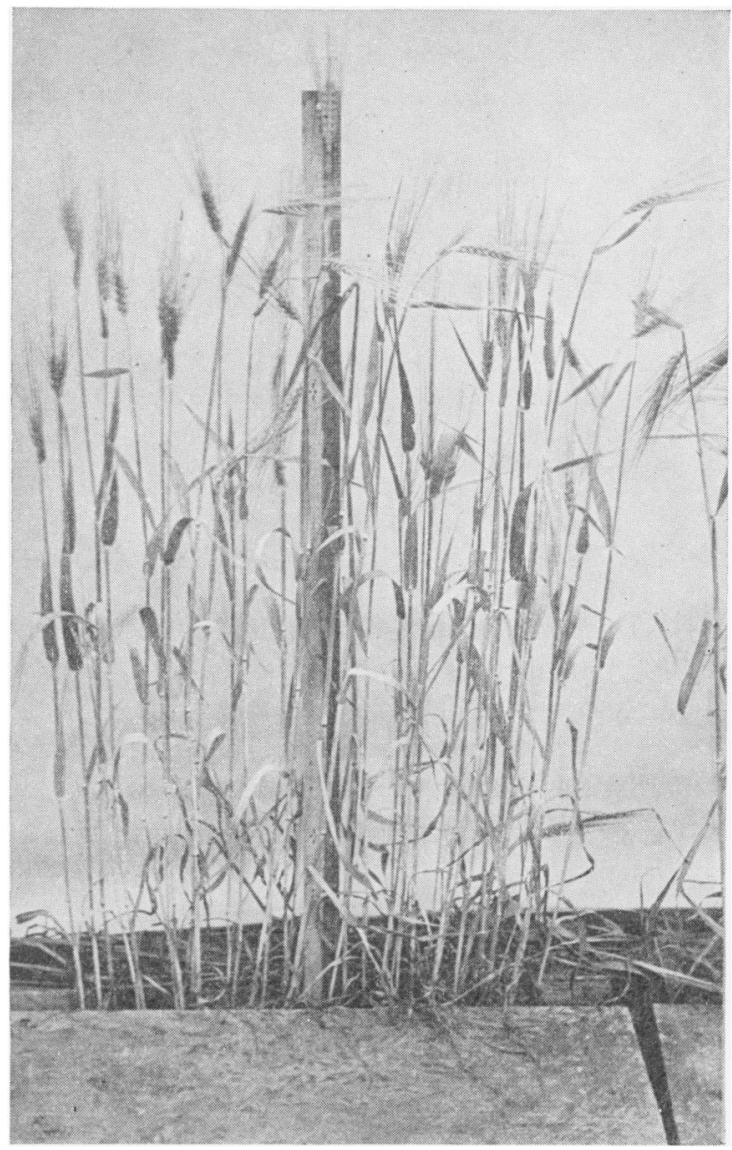

FIG. 8.-Mature crops: with phosphates at I-I.5 foot depth respectively

That nitrogen promotes tillering is well known. These experiments show that the addition of more nitrogen below the surface foot makes the tillering habit even more pronounced. GERICKE (7), in accounting for the abundant tillering and culm production in cultures of wheat which received additional supplies of nitrogen 
late in the growing period, concluded that it was due to the greater extent of the root system. This resulted in the absorption of a larger amount of nutrients than was needed by the plants for normal development of the individual shoots. Our results are in agree-

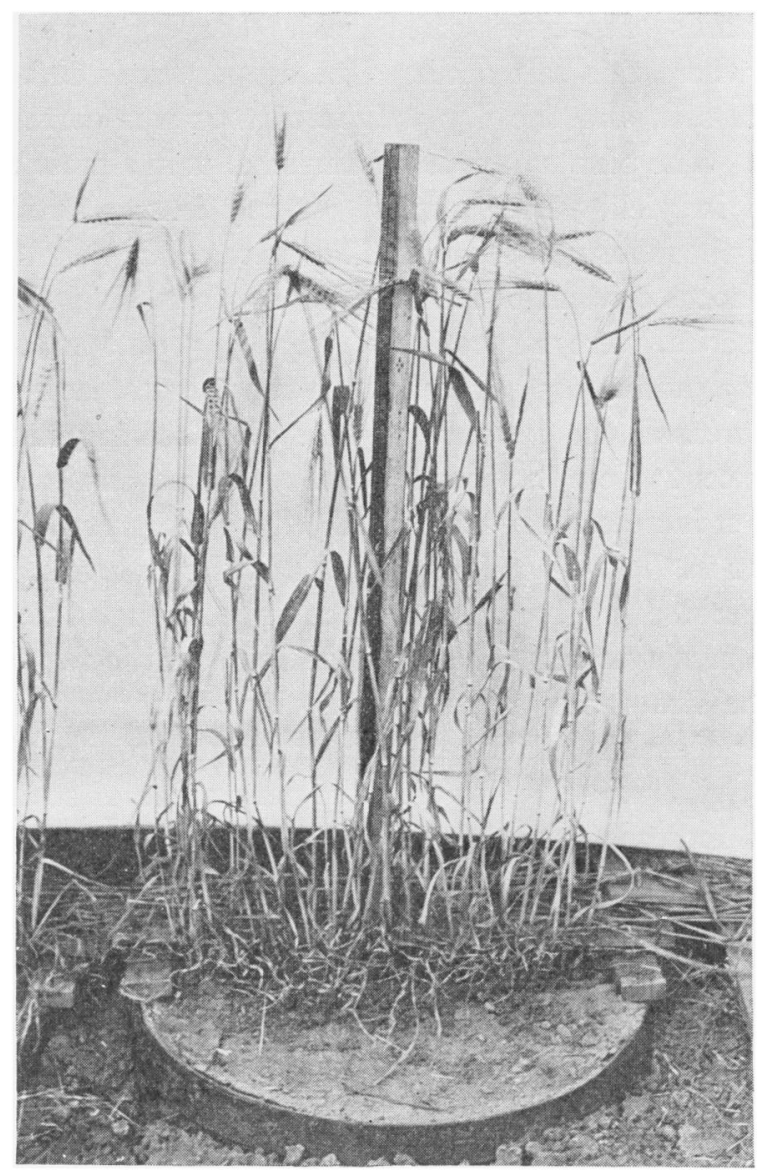

Fig. 9.-Mature crops: control, not fertilized

ment with this explanation. The number of stalks followed closely the amount of nitrate absorbed, and even more closely the nitrogen content of both grain and straw at maturity. Moreover, the amount of tillering correlated closely with the root area in contact with the nutrient, if we consider that the extent of the root systems 
in the successive layers of the singly fertilized soils was progressively less from the surface foot downward, and greater in any soil doubly fertilized. The growth period of the plant, however, seems to affect the rate and significance of absorption more or less aside from the extent of root development.

Phosphorus depressed the yield. Larger quantities were absorbed where this salt occurred at deeper levels in addition to the surface soil, and the dry weight of tops was correspondingly depressed. The plants were fewer and smaller in almost every way. Reduction in yield varied almost directly in proportion to the amount of phosphorus absorbed. The average dry weight and average phosphorus content of straw of the controls, singly and doubly fertilized series, were respectively, 53.7, 43.5, and $28.4 \mathrm{gm}$., and $0.301,0.423$, and 0.565 per cent. In most cases, however, phosphorus increased the percentage of stalks bearing heads, while nitrates, except where they occurred below 2 feet, caused a decrease.

Nitrogen increased absolute yield only when present in the surface foot or in the surface foot as well as in lower levels. In either case the increase was brought about mainly through the straw and averaged greater under the second set of conditions. This effect through the straw was wrought simply by an enormous increase in the number of stalks. Nitrate depressed height growth, reduced the average weight per stalk, lowered the percentage of stalks bearing heads, and increased the total number of heads and their average length but little. It exerted only a slight influence upon the weight of the grain, yet the increase in the total number of stalks was sufficient to overcome these losses, and indeed to give increased totals. Unlike phosphorus, it lowered the ratio of the dry weight of grain to straw. This effect appeared where the plants absorbed more than I35 p.p.m. of $\mathrm{NO}_{3}$, or where the straw contained above I per cent and the grain above 2.5 per cent of nitrogen. HELlRIEGEL and WILFARTH (I2), working with sand cultures, obtained no further increase in the ratio of grain to dry matter of barley when the cultures were supplied with more than I68 mg. of nitrogen. HELLRIEGEL (I3) also found that the percentage of grain to total dry weight of barley decreased when more than II3.6 mg. of $\mathrm{P}_{2} \mathrm{O}_{5}$ were supplied per pot. 
The amount of nutrient removed from the soil is not the only factor affecting quality and quantity of yield. As regards nitrogen particularly, much seems to depend upon the time when the salts are available. Placing the fertilizer in the several containers in progressively deeper soil layers is really a means of varying the time in the life of the plant when the salt is available. And, since presumably roots absorb from deeper soil layers somewhat in proportion to the time they occupy these layers, it also varies the amount of fertilizer absorbed. Thus, as the time of nitrate absorption became progressively later in the life of the crop in the soil singly fertilized, so the number of stalks and heads, the nitrogen content of the straw, and, to a less degree, the nitrogen content of the grain decreased. Moreover, the same held true for the dry weight of both grain and straw and the average length of heads, where the fertilizer occurred above 2 feet. Where the nitrate occurred below 2 feet there was a relative increase in weight of grain and straw as well as length of heads, instead of a further decline. This occurred also in the doubly fertilized soils, where in addition gains were made in the nitrogen content of the straw, number and average length of stalks, number of heads, and percentage of stalks bearing heads. Thus applications of nitrate are most beneficial to the quantity and quality of the crop in the earliest and latest stages of root development and activity, although they are not entirely ineffective at certain intermediate stages.

The relation of the growth period of the plants to the effectiveness of the phosphorus was less marked, although very definite in some respects. As the contact of the roots with the fertilized layer was delayed, there was a progressive decrease in the number of stalks, dry weight of both grain and straw, and phosphorus content of grain.

GERICKE (8) applied sodium nitrate to spring and winter wheat, oats, and rye growing in soil in one gallon stone jars, at different growth periods. In the spring wheat and oats, the nitrogen or protein content increased continuously as the applications were made later and later in the life of the plant. Winter wheat and rye gave a like response only to applications made in the latest periods of growth. The barley in our experiment responded differ- 
ently from these crops, in that the plants decreased in nitrogen content and in tillering as the availability of the nitrate was postponed through the mechanism provided in the singly fertilized series. GERICKE (9) confirmed his results regarding the relation he found between the time of application of nitrate salts and the resultant protein content of oat plants. He used a sandy soil deficient in nitrogen, and grew 7 plants in each one gallon container in a greenhouse. He found an increase in the number of stalks, but a decrease in their average height as the nitrate was applied later in the life of the plant. He believes the shorter stalks may be either a result of competition or due to the late production of tillers and their correspondingly shorter period for growth. Moreover, he found total dry weight and the weight of the grain to be greater when the nitrate was applied later in the life of the crop. In every respect these results are quite the converse of those set forth in this paper, and the reason for the difference seems to lie in the method of experimentation. It seems clear that cereal crops with roots which normally reach depths of $3-5$ feet and spread laterally through a radius of 12 inches (WEAVER I9, 20) might function quite differently when several plants were confined to $5.5 \mathrm{~kg}$. of soil.

Davidson and Le Clenc (3), working with wheat grown in outdoor plats, applied $\mathrm{NaNO}_{3}$ at the surface at different periods of growth with the following results. Applications made early (plants 2 inches high) stimulated vegetative growth and consequently increased yield; applications made at the milk stage of the grain had no effect on either yield or quality; while applications at heading time gave a better quality of grain as to color and protein content, but the vegetative growth was unaffected. In I922, DAVIDSON (4) again grew wheat in field plats of one square rod each and applied nitrates at different growth periods. The effectiveness of the nitrogen in increasing yield gradually decreased as the nitrate was applied later and later in the life of the plant. Its effectiveness, however, in increasing protein content of grain and percentage of grain to total dry weight of crop was increased. The data in table IV bear out these results except the effect upon the protein content of grain. 
BURD (2) grew barley in containers with a surface area of $30 \times 60$ inches each and a depth of 18 inches. He concludes that the two elements (potassium and nitrogen) with which plant growth in general is most closely associated may approach or exceed their maxima at a comparatively early stage in the plant's development, that is, at the beginning of head formation; also that the mutual relations of soils and plants are such that it is generally desirable to have the large amounts of solutes incidental to relatively high concentrations in the soil solution at the commencement of the plant's growth cycle, but that it is unnecessary and may be undesirable to maintain this condition during the later stages of growth.

As regards nitrates, our results do not confirm this conclusion. WEAVER (20) has shown that the roots of barley when grown in a column of soil of adequate depth do not reach the lowest levels of their penetration to any considerable extent, and consequently do little absorbing there until the plants are nearing the blossoming stage. Root activities during the critical periods of blossoming and the filling of the grain have been shown to be exceedingly important. GILE and CARRERo (Io), working with rice and corn where a part of the roots only were in contact with nitrogen or phosphorus in a complete solution, have shown that the smaller the portion of the roots in the complete solution the greater was the absorption of the elements per gram of roots.

Differences in the results obtained by various investigators on the use of nitrate fertilizers no doubt are due, at least in part, to the different crops and experimental methods employed. Moreover, it is possible that the effect of nitrates upon the development of a plant is determined in some measure by the portion of the root system in which the absorption occurs. Perhaps a smaller percentage of nitrate absorbed by the roots from the deeper soil levels actually reaches the above-ground parts, being used up in the metabolic processes of the roots themselves. If this is the case, the arrangement of the fertilized layers in the containers in this experiment would serve to make the results evident.

The fact that roots absorb nutrients at deep levels in the subsoil as well as from the surface layer should be given greater attention by all plant growers. The current idea that it is mainly the surface 
layer of soil that supplies the plant with nutrients and that the subsoil is the crop's reservoir for water, should give way to the fact that it is the whole soil mass pervaded by roots that determines root activities. Since not only the quantity of nutrients but also the time at which they are absorbed affect quantity and quality of yield, the amount of available nutrients in the subsoil is a matter of great importance. In fact, the adaptability of a soil for crops may be determined largely by the composition of the subsoil. The problem of getting the phosphatic and potassic fertilizers, which do not leach extensively into the deeper soil where they may be more efficient, is one with which students of fertilizer practices should be concerned. The time and quantity of the applications of nitrates, which leach freely into the deeper soil, in relation to rainfall and root depth is a field worthy of investigation. It is possible that tillage and cultivation practices can be modified so as to give in advance of the crop season a supply of nitrates which might leach into the deeper subsoil in time for their absorption at the most effective period in the development of the crop.

\section{Summary}

I. This investigation was undertaken to determine the effects of absorption of nitrates and phosphates from the subsoil on quantity and quality of yield of barley. Eighteen containers, 22 inches in diameter and 30 inches deep, were filled with soil and subsoil and placed in trenches in the field. Thirty barley plants were grown in each container; they were surrounded by a crop of barley, growing partly in the refilled trenches. The soil, except in the controls, was fertilized at various levels to 30 inches in depth, and in some cases at two levels, with either $\mathrm{NaNO}_{3}$ or $\mathrm{CaH}_{4}\left(\mathrm{PO}_{4}\right)_{2}$. Wax seals, through which the roots easily penetrated, were used to prevent the movement of water and nutrient salts from the fertilized layer to the soil above or below.

2. The roots in the controls reached a depth of 30 inches, but nitrate fertilizer at any level tended to lessen root depth and greatly increased branching. Phosphates did not noticeably increase root development.

3. Nutrients were absorbed in large quantities at every level to 30 inches. Although the plants used the largest amount of salts 
from the surface foot, they also took large additional quantities from the deeper levels when it was available.

4. Absorption of nutrients at levels below the surface foot affects materially the quantity and quality of the yield. It does not lose its additive effect even when the surface foot is abundantly supplied with a similar nutrient. Thus the chemical composition of the subsoil and the soil solution is very important.

5. Nitrates increased total dry weight when applied to the surface foot early in the life of the plant. This results from its effectiveness in promoting heavier tillering. It increased dry weight and also quality of grain still more when available at lower levels as well as in the surface foot. Phosphorus depressed yield, particularly that of the straw, somewhat in proportion to the amount absorbed.

6. Time of absorption is an important factor. The effects of the nutritive salts are most marked on both quantity and quality of yield early and late in the development of the plant, that is, when absorption is confined largely to the first foot of soil and the crop is tillering, and again when the younger portions of the longer roots are absorbing from the deeper levels at the time of heading. Thus an ample distribution of the deeper portion of the root system in a rich subsoil solution at the later critical period of growth is exceedingly important. Consequently, a knowledge of the development and extent of the roots of crop plants is of primary interest.

7. These experiments show the importance of the subsoil as a source of nutrients for crops, and the effects upon plant development. They emphasize the values to be gained by fertilizer practices which take the composition of the subsoil into account.

UNIVERSITY OF NEBRASKA

LIncoln, NEB.

\section{LITERATURE CITED}

r. BRenchley, W. E., and JaCkson, V. G., Root development in barley and wheat under different conditions of growth. Ann. Botany 35:533-556. I92I.

2. BURD, J. S., Rate of absorption of soil constituents at successive stages of plant growth. Jour. Agric. Res. I8:5I-72. I9I9.

3. Davimson, J., and Le Clerc, J. A., The effect of sodium nitrate applied at different stages of growth on the yield, composition, and quality of wheat. Jour. Amer. Soc. Agron. 9: I45-I54. I9I 7. 
4. Davidson, J., The effect of nitrates applied at different stages of growth on the yield, composition, and quality of wheat. Jour. Amer. Soc. Agron. 14:II8-I 22. I922.

5. Frank, B., Die Assimilation des freien Stickstoffs durch die Pfanzenwelt. Bot. Zeit. 51:139-156. I893.

6. Fraps, G. S., Active phosphoric acid and its relation to the needs of the soil for phosphoric acid in pot experiments. Texas Agric. Exp. Sta. Bull. I26. I9I0.

$\rightarrow$ GERICKE, W. F., Certain relations between root development and tillering in wheat: significance in the production of high-protein wheat. Amer. Jour. Bot. 9:366-369. I922.

8. _ Differences effected in the protein content of grain by applications of nitrogen made at different growing periods of the plants. Soil Science 14:103-109. 1922.

9. - Studies on the effect of nitrogen applied to oats at different periods of growth. Jour. Amer. Soc. Agron. 14:31 2 320. I922.

io. Gile, P. L., and Carrero, J. O., Absorption of nutrients as affected by the number of roots supplied with the nutrient. Jour. Agric. Res. 9:73-95. I9I7.

II. Höveler, W., Über die Verwerthung des Humus bei der Ernährung der chlorophyll-führenden Pflanzen. Jahrb. Wiss. Bot. 24:283-3I6. I892.

I2. Heliriegel, H., and Wilfarth, H., Untersuchungen über die Stickstoffnahrung der Gramineen und Leguminosen. Zeitsch. Vereins Rübenzucker-Industrie. I888:16, 33, 42 .

13. Hellriegel, H., et al, Vegetationsversuche über den Kalibedarf einiger Pflanzen. Arb. Deutsch. Landw. Gesells. I898:34, 39, 40, 42, 45.

14. Livingston, B. E., Note on the relation between growth of roots and of tops in wheat. Bot. GAZ. 4I:I39-I43. I906.

15. MÜller-Thurgau, H., Einfluss des Stickstoff auf die Wurzelbildung. Jahresb. Vers. Stat. Schule Wädensweil 4:48-52. I894.

r6. NоввE, F., Über die feinere Verästelung der Pflanzenwurzeln. Landw. Vers. Stat. 4:2I 2-224. I862.

17. Seelhorst, C. von, Beobachtungen über die Zahl und den Tiefgang der Wurzeln verschiedener Pflanzen bei verschiedener Düngung des Bodens. Jour. Landwirtschaft. 50:9I-I04. I902.

I8. Thuse, H., Der Text zu den Wandtafel für den naturwissenschaftlichen Unterricht. Bewurzelung. Berlin. I876.

I9. Weaver, J. E., and CRIST, J. W., Relation of hardpan to root penetration in the great plains. Ecology 3:237-249. 1922 .

20. Weaver, J. E., Jean, F. C., and Crist, J. W., Development and activities of roots of crop plants. Carn. Inst. Wash. Publ. no. 3I6. I922.

2r. Whiting, A. L., Richards, T. E., and Schoonover, W. R., Nitrate determination in soils. Jour. Ind. and Eng. Chem. 12:982-984. I920. 